\title{
The Performance of Thai Mutual Funds: A 5-Star Morningstar Mutual Fund Rating
}

\author{
Chollaya Chotivetthamrong
}

\begin{abstract}
Due to Tax-benefit from Thai government's regulation, most of investors are interested in Thai mutual funds. Thus, it brings the important question that which is the right indicator or method to help investors making decision? Based on their knowledge?

This paper studies popular methods that unsophisticated and sophisticated investors always use, which are Morningstar rating, and flow-performance sensitivity respectively. This paper examines, and monitors for 36 Thai "star" funds from 2003 to 2007 by using fama-french model.

The result suggests that there is a positive relationship between funds' sensitivity and Morningstar rating. Thus, even sophisticated or unsophisticated investors use different method in investment decision making, they will go to the same direction. In addition, this paper proofs that after funds receive as high performance star as five-star. Their performances drop, mainly from fund size.
\end{abstract}

Index Terms-Mutual Fund performance, mutual fund rating, Morningstar mutual fund, investor decision making, fama-french model

\section{INTRODUCTION}

In 2002 and 2004, Thai government announced a tax-benefit for the ones who buy Retirement Mutual Funds (RMF), and Long-term Equity Funds (LTF) respectively. Reference [1] mentioned that due to this tax-benefit, it increases a number of long-term investors to invest in Thai mutual funds.

For that reason, it brings some questions as how the investors decide to invest in which mutual funds to gain high return especially in emerging market, which has less information. As a result, most of the investors go to use one of the most popular key indicators to show funds' performance that is rating.

Morningstar rating is one of the well-known ratings, which has been introduced by Morning star, Inc. Morning star, Inc. is a worldwide service provider for investor. This Morningstar rating is one of the indicators to help investor for decision making. As result, most of the investors are interested in the recommend one, known as 5-star. They hope that that those funds are good performance or will gain higher return.

Reference [2] explained that especially for unsophisticated investors, they tend to attract in "star" funds rather than "non-star" funds. In contrast, sophisticated investors use the effect of volatility on the flow-performance sensitivity. As a

Manuscript received September 13, 2013; revised November 15, 2013. This work was supported in part by the National Institute of Development Administration, Bangkok, Thailand.

Chollaya Chotivetthamrong is with the National Institute of Development Administration, Bangkok, Thailand (e-mail: ja_san@live.com) result, to understand the investment decision, the study should understand both of the trend of "star" funds, and the funds' sensitivity.

The paper evaluates "star" mutual funds' performance per year (from 2003 to 2007) to report trend of each fund in each year. In addition, as sophisticated investors use the effect of volatility on the flow-performance sensitivity for their investing decision, this paper examines the trend of funds' sensitivity in part of Fama-French momentum alpha, comparing with funds' performance in term of Morningstar index.

This paper will be divided into four sections. In the first section, it will be reviewed the literature. It will present data selection, and empirical methodology. Then it will present empirical results. The last section contains the conclusion.

\section{REVIEW OF LITERATURE}

\section{A. Morningstar Index}

Reference [3] was introduced the Morningstar Category classifications in 1996 that helped investors make meaningful comparisons between mutual funds. The categories help investors identify the top-performing funds, assess potential risk, and build well-diversified portfolios. Morningstar regularly reviews the category structure, and the portfolios within each category to ensure that the system meets the needs of investors.

\section{B. Morningstar Category and Performance}

To categorize the funds, Morningstar Category separates rating level as bell curve, shown in Figure 1 [3]. Morningstar presents rating level by star symbol (*).

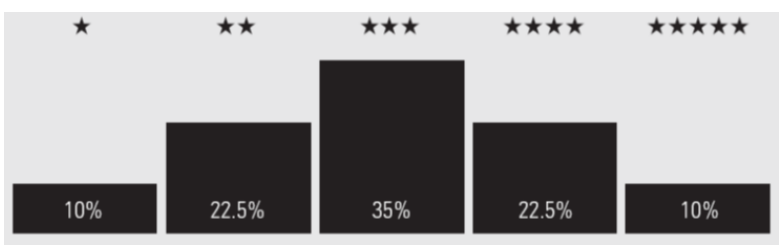

Fig. 1. Morningstar index bell curve [3]

TABLE I: THE PERCENTILE FOR MORNINGSTAR INDEX

\begin{tabular}{lll}
\hline \hline \multirow{2}{*}{ From Percentile } & To & Category \\
& Percentile & Rating \\
\hline 0 & 10 & 1 \\
10 & 32.5 & 2 \\
32.5 & 67.5 & 3 \\
67.5 & 90 & 4 \\
90 & 100 & 5 \\
\hline \hline
\end{tabular}

Fig. 1 shows how to categorize the funds. Morningstar Category separates rating level as bell curve, and rates level 
by star symbol as percentile range.

The ranks are used to assign each fund a rating from 1 to 5 , with 5 assigned to the best funds in the group, and 1 to the worst. Morningstar separates each star by percentile as Table I.

Table I explains how Morningstar Index separates the group of funds by percentile range. The ranks are used to assign each fund a rating from 1 to 5 , which 5 assigned to the best funds in the group and 1 to the worst.

Reference [4] found that the Morningstar rating has a significant effect on fund flows. They find that when fund gets the 5-star rating, the investors are more interested in the funds. As a result, the fund's inflows increase around 53 percent above the normal flow.

Reference [5] examined the predictive qualities of the entire Morningstar rating system. They measured the effects of suddenly result after funds get Morningstar, and identify the breaking point in performance, and portfolio turnover.

According to the importance of Morningstar rating to mutual fund's flow, there are several papers that studied in Morningstar rating with funds' performance. Moreover, they suggested that the rating can foresee the future return, and help the investor to make the proper investment decision.

Reference [6] studied how mutual fund performance related to their past performance. They tested by analyzing a multiple portfolio benchmark, and formed on the basis of securities characteristics. They tested 279 funds from December 31, 1974 to December 31, 1984, which were purchased from CDA Investment Technologies, Inc.. They found that the funds' performance changed over time period. The persistence cannot be explained by the benchmark that are related to firm size, dividend yield, past returns skewness, interest rate sensitivity, or CAPM beta.

After this study, there are several studies that are presented in predicting future performance for mutual fund. First, Reference [7] examined the mutual funds, and measured performance of those funds within one year by using risk-adjusted returns. They found that if the funds did well in the past, it trended to do well in the future.

Another paper by [8], they found different story from previous paper, [7], they examine an initial 5-star Morningstar mutual fund rating, and predict the future performance after 3 years. They found that after fund received the 5-star rating, the fund performance severely falls off, mainly from higher risk levels of funds. They explained that there is a negative relationship between large fund inflows, and future performance.

However, some investors considered not only on "star" funds but also the dampening effect of volatility on the flow-performance sensitivity. As stated in several empirical studies, they explained that there is a simple relation between conditional returns and volatility [see, e.g., [9]-[11], and [12].

Reference [13] stated that there is a strong relationship between mean returns and volatility. Reference [14] agreed with the study. He studied that volatility is an important factor in the returns of the mutual funds, and has led to higher risk-adjusted returns. Moreover, he documented that there is a significant relationship between volatility and the investment performance. The volatility affected to high systematic risk, causing low returns.

Reference [15] agreed with the previous paper, [14], that more volatile performance provided a noisier signal, and reduced the flow-performance sensitivity.

This paper differs from past articles on funds' performance. This paper will examine the funds' performance in the short term period (5-year) in the emerging market as Thailand, which the most of the papers are interested in developed market as US or UK market, which should provide the same or difference result from those markets. In addition, this paper will compare the result of funds' performance with funds' risk to understand in the investor decision making.

Moreover, the paper will test by using Fama-French momentum Alpha for analysis, and using pair t-test for testing the hypothesis for the funds' performance, and compare with funds' rating.

For Thailand, Fama-French model should be added one more factor that is liquidity [16]. He explained that only three factors in Fama-French model cannot explain the excess expected stock return in Thai stock market; however, liquidity-augmented model is a more appropriate choice in explaining Thai stock returns. This method will identify the funds' performance, and forecast the future performance.

Moreover, there is another important question to understand funds' performance. How does performance depend on the size of the fund? There are several empirical researches that study in the effect of funds' size with funds' return. Most of the studies (e.g, [17]) illustrated that a large asset had negative relationship with funds' return or price. A small fund can easily manage. The manager can put all of its money in its best ideas with a lack of liquidity; whereas, a large fund has to invest not-so-good ideas with more liquidity. Thus, it eroded performance.

As a result, based on the previous studies, this paper will examine the correlation between fund size and funds' performance, based on Morningstar index.

In the Thailand, Morningstar maps into 3 broad asset classes that are Equity, Balanced, and Fixed Income. The method for Morningstar rating refers to risk-adjusted returns. It adjusts the risk between 2 funds to be equal, and then compare the return by using Sharpe Ratio.

\section{DATA SELECTION}

Previous papers (e.g., [18]-[23]) are interested in performance persistence in mutual funds were selected funds by using single or multi-index alphas to define winning funds, and run the testing.

This paper would like to measure the mutual funds and returns, using Morningstar funds in the period of 5 years (between 2003 and 2007). There are 36 "star" Thai mutual funds from the 2003 to 2007 , and monitored the mutual funds' rating in the short run (five years after receiving funds' rating) as annually, including the volatility for Thai mutual funds within this 5 year. In addition, the paper uses four-factor model (Fama-French four factors model) to examine the returns, comparing with funds' rating.

To calculate Fama-French momentum alpha, the paper collects monthly return data of mutual funds from Stock Exchange of Thailand (SET), starting from 2003 to 2007 for 5-star Morningstar ratings. Moreover, the interest rate of monthly of THB LIBOR will be used as a risk-free rate. 


\section{EMPIRICAL METHODOLOGY}

There are 4 processes for Morningstar Risk Adjusted Return or MRAR [24] that are calculate monthly return, adjust return with dividend or called as Load-Adjusted Return, and trade-off between Monthly Risk-Adjusted Return and Risk. All Morningstar equations as below refer to [24]:

\section{A. Monthly Returns}

A primary ingredient in all the Morningstar calculations is the set of historic monthly rates of return for the funds. The rate of return for funds i month $t$ is show as in (1):

$$
R_{i t}=\frac{\left(E V_{i t}+E V D_{i t}-E V_{i} t-1\right)}{E V_{i t,-1}}
$$

where:

$E V_{i t}=$ closing net asset value on the last trading day of month $\mathrm{t}$

$E V D_{i t}=$ closing net asset value on the last trading day of month $\mathrm{t}$ of distributions taken as shares in month $\mathrm{t}$

$E V_{i, t-1}=$ closing net asset value on the last trading day of month $\mathrm{t}-1$

$R_{i t}=$ rate of return for fund i month $\mathrm{t}$

In general, distributions are reinvested in the fund's shares at the closing net asset value on the "ex-distribution day".

\section{B. Monthly Excess Returns}

For many calculations, excess returns are utilized. The excess return for fund $i$ in month $\mathrm{t}$ is the difference between the fund's return for the month and the return on a 90-day U.S. Treasury bill for that month is shown as in (2):

$$
E R_{i t}=R_{i t}-B_{t}
$$

where:

$E R_{i t}=$ the excess return on fund $i$ in month $\mathrm{t}$

$B_{t}=$ the return on a Treasury bill in month $\mathrm{t}$

$R_{i t}=$ rate of return for fund $i$ month $\mathrm{t}$

\section{T-Period Value Relative}

A traditional measure of performance in the mutual fund industry is the cumulative value of $\$ 1$ compounded over a specified number of periods. Morningstar uses such measures on both before-load, and after-load fee bases. The value relative at the end of $\mathrm{T}$ periods not taking any load charges into account is shown as in (3):

$$
V R_{i}=\operatorname{prod} t=1, \ldots T\{1+R i t\}
$$

where

$V R_{i}=$ the $T$-period value relative for fund $\mathrm{i}$

$\operatorname{prod}_{t=1, . . T\{\}}$ denotes the product of the expressions in the brackets with $t=1,2, . ., T$

\section{Excess T-Period Value Relative}

For some calculations, Morningstar compares the cumulative value of $\$ 1$ invested in a fund with the cumulative value of $\$ 1$ invested in Treasury bills. The latter is shown as in (4):

where:

$$
V R B=\operatorname{prod} t=1, \ldots, T\{1+B t\}
$$

$V R B=$ the $T$-period value relative for Treasury bills

$\operatorname{prod}_{t=1, . . T\{\}}$ denotes the product of the expressions in the brackets with $t=1,2, \ldots, T$

\section{E. Morningstar Category Return}

To provide a normalized measure of returns of funds within each category, Morningstar divides each fund's excess 36 -month value relative by a base figure. For each category, the base is the larger of (1) the average excess 36-month value relative for the funds in the category or (2) the 36 -month value relative for Treasury bills -1 . The moringstar category return is shown as in (5):

$$
\operatorname{msCRet}_{i}=\frac{E V R_{i}}{\operatorname{RetBasec}_{i}}
$$

where:

msCRet $_{i}=$ Morningstar's category return for fund $i$

RetBasec $_{i}=$ the return base for fund $i$ 's category and:

$$
\operatorname{RetBasec}_{i}=\max \left\{\operatorname{avg}_{j} \text { in } c\left\{E V R_{i}\right\}, V R B-1\right\}
$$

where:

$a v g_{j}$ in $c\{\}$ indicates the average of the term in the brackets for funds $(j)$ in category $c$

If the category returns are high enough for the first of the two formulas above to be utilized, the average of the category returns for the funds within a category will equal 1.0. Otherwise, it will be less than 1.0.

\section{F. Average Monthly Loss}

Morningstar's measure of risk is based on the extent to which a fund's returns fell below those of Treasury bills. The first step in such calculations involves the calculation of a fund's loss in each month, defined as the smaller of its excess return, and zero is shown as in (7):

$$
L_{i t}=\min \left\{E R_{i t}, 0\right\}
$$

where:

$L_{i t}=$ fund $i$ 's loss in month $t$

The Average Monthly Loss for fund $i$ is its average loss over $T$ periods is shown as in (8):

$$
A M L_{i}=\frac{\operatorname{sum}\left(L_{i t}\right)}{T}
$$

where:

$A M L_{i}=$ fund $i$ 's average monthly loss over $T$ periods

\section{G. Morningstar Category Risk}

To compute a measure of relative risk for each fund in a category, Morningstar divides each fund's average monthly loss is shown as in (9), and in (10) by the average of such values for all funds in the category:

$$
\begin{aligned}
\text { msCRisk }_{i} & =\frac{\operatorname{AML}_{i t}}{\text { RiskBase }_{i}} \\
\text { RiskBasec }_{i} & =\operatorname{avg}_{j} \text { inc } c\left\{A M L_{i}\right\}
\end{aligned}
$$

where: 
$m s$ RRisk $_{i}=$ Morningstar's category risk for fund $i$

RiskBasec $_{i}=$ the risk base for fund $i$ 's category

Whereas the average monthly loss for a fund will typically be negative, so will the risk base for its category. Thus the Morningstar category risk values will all be positive, and the values for the funds within a category will average to 1.0.

\section{H. Morningstar Category Rating}

Morningstar combines a fund's category return and category risk to compute a category risk-adjusted rating as shown as in (11):

$$
\operatorname{msCRAR}_{i}=\operatorname{msCRet}_{i}-\operatorname{msCRisk}_{i}
$$

where:

$m s C R A R_{i}=$ Morningstar's category risk-adjusted rating

These values are then ranked, and converted to category rating percentiles, with the largest value assigned to the 100 'th percentile, and the lowest to the first percentile. Finally, category ratings are assigned based on the percentile rankings of the funds within the category.

In this paper, it focuses on Morningstar from 2003-2007, which are distributed by Morningstar, co., and provided data for public in the internet, refer to [25].

\section{Fama and French Four-Factor Model}

This paper examines the returns of the "star" funds by comparing over time period as 5-year. Reference [8] examined that after US mutual funds receive the 5-star index, the performance drops significantly. He used mean and median method. If the change of the significant of coefficient in both mean and median are in positive, it means that the funds' performance are better after receiving the 5-rating for 3 years.

Reference to [26] was developed the Fama-French three-factor model to examine a time-series regression. This approach was explained by the sensitivity of its return to three factors that are the excess return on a broad market portfolio (MP), the difference between the return on portfolio of small stocks and the return on large stocks (SMB), and the difference between the return on a portfolio of low-book-to-market stocks (HML).

However, reference to [27] studied that Thai stock market cannot be used traditional Fama-French three-factor model to explain on the excess expected returns.

He mentioned that in Thai Stock market, there is another factor in the factor-model that is liquidity. The paper's results were shown that the liquidity is priced in Thai common stocks, and liquidity-augmented model significantly improves the explanation power on the excess expected stock returns over the traditional model. As a result, the model is as in (12),

$$
\begin{aligned}
R_{p t}-R_{f t}=a p & +b p M P_{t}+s p S M B_{t}+h p H M L_{t} \\
& +y p L I Q_{t}+c
\end{aligned}
$$

where

$R_{p t}-R_{f t}=$ portfolio excess returns

$M P_{t}=$ market excess returns

$S M B_{t}=$ the size factor
$H M L_{t}=$ the book-to-market factor

$L I Q_{t}=$ the liquidity factor

$\varepsilon p_{t}=$ the error term

$$
\begin{gathered}
S M B=\frac{-\left(\frac{S}{L}-\frac{B}{L}\right)+\left(\frac{S}{M}-\frac{B}{M}\right)+\left(\frac{S}{H}-\frac{B}{H}\right)}{3} \\
H M L=\frac{-\left(\frac{S}{H}-\frac{S}{L}\right)+\left(\frac{B}{H}-\frac{B}{L}\right)}{2} \\
L I Q=\frac{-\left(\frac{S}{L 1}-\frac{S}{L 3}\right)+\left(\frac{B}{L 1}-\frac{B}{L 3}\right)}{2}
\end{gathered}
$$

where

The average firm size is considered as a small $(S)$, and the big firm $(B)$

The Book-to- Market ratio is Low $(L)$, Medium $(M)$, and High $(H)$

The liquidity proxies is most illiquid $(L 1), L 2$, most liquid (L3)

As of those previous studies, this paper examines the funds' performance by finding the Fama-French momentum alpha from this liquidity four-factor model, and monitors a trend of alpha for comparison with funds' rating to understand the trend between those indicators, and find the relationship.

\section{EMPIRICAL RESULTS}

\section{A. Fund's Rating}

Based on empirical studies, most of 5-Morningstar funds dropped their performance after receiving 5-Morningstar in US market. However, to test for Thailand, the paper monitors the funds' rating during 5 years started 2003 to 2007 as shown in Table II [25].

Table II is illustrated that only $22 \%$ or 8 funds out of 36 funds increase their performance within 5 years. In addition,

We can separate the funds into 3 groups that are above-average funds (4-Morningstar funds, and 5-Morningstar funds), average funds (3-Morningstar funds), and below-average funds (2-Morningstar funds, and 1-Morningstar funds). Most of above-average and average funds dropped their performance within 5 years; however, the below average ones increased or stayed stable their performance. Moreover, most of the funds in all groups are stabled their performance in the 5 th year.

\section{B. Fama-French Momentum Alpha}

Reference [12] stated that most mutual fund studies prior to the 90 s use CAPM based single index model. The intercept of such a model, $\infty$, gave the Jensen alpha, which measured out or under-performance. Because of the wired diversity of investment styles, single index cannot cover.

After that, most of the empirical studies prefer to use a multi-factor model for all possible investment strategies. Fama and French 3-factor model has been considered to give a better explanation of fund behavior. Although this model already improved from CAPM pricing errors, it is not able to explain the liquidity of Thai funds' portfolio. Therefore, reference [27] extended the Fama-French model by adding a fourth factor that captured the liquidity. 
TABLE II: MORNINGSTAR FUNDS’ PERFORMANCE BY EACH YEAR (FROM 2003 TO 2007) [25]

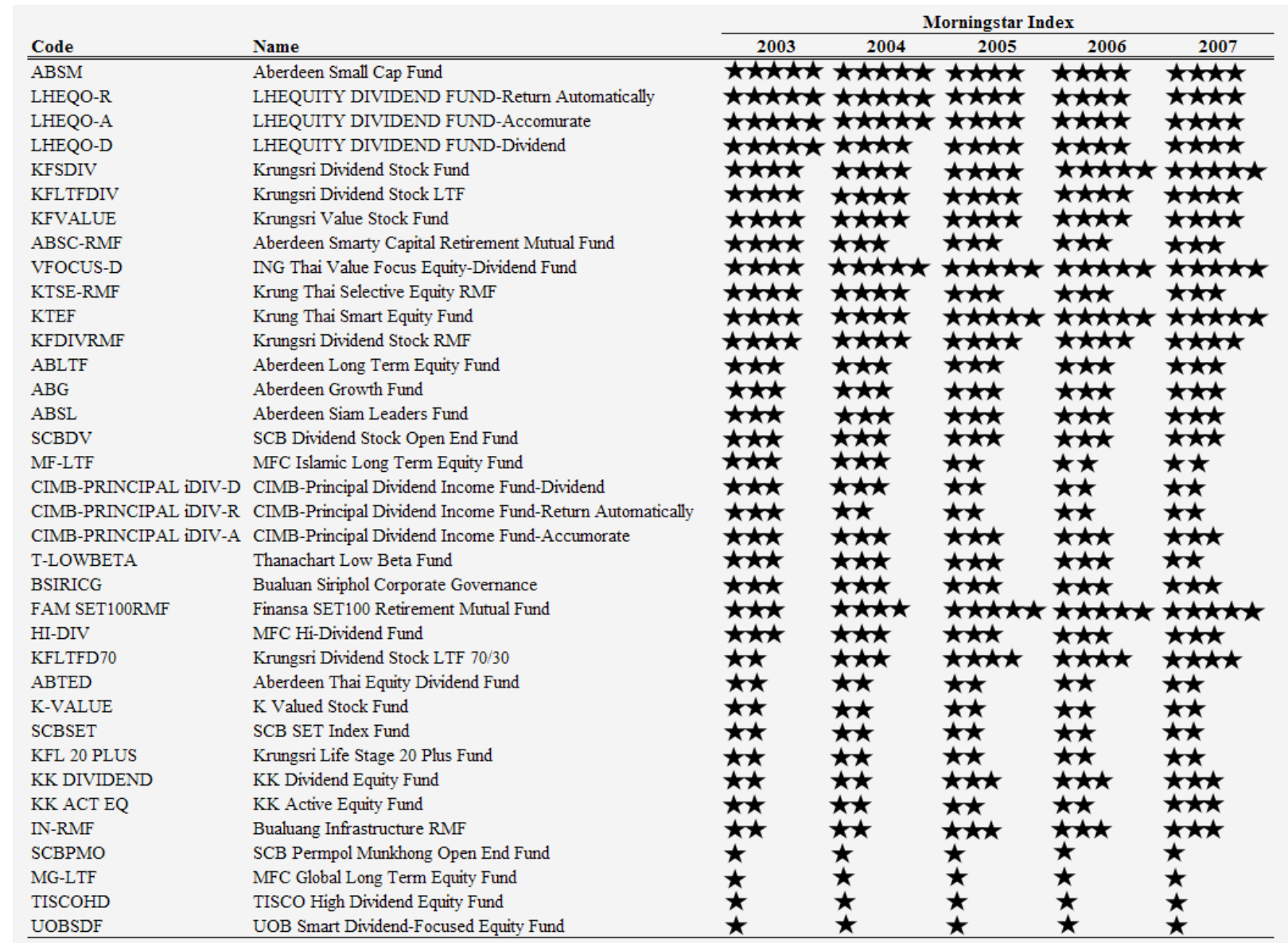

Table II is shown Morningstar funds' performance each year, started from 2003 to 2007, distributed to public by Morningstar Co.

For this reason, the paper examines to find Fama-French momentum alpha to find the average alpha for each Morningstar index as shown in Table III.

Table III examines the average of Fama-French Momentum alpha for Morningstar funds. The "5-star" funds have highest value and decrease respectively.

TABLE III: AVERAGE FAMA-FRENCH MOMENTUM ALPHA

\begin{tabular}{lll} 
"Star" Rating & Average Alpha \\
\hline$\star \star \star \star \star$ & & 0.91 \\
$\star \star \star \star$ & & 0.76 \\
$\star \star \star$ & & 0.58 \\
$\star \star$ & & 0.38 \\
$\star$ & & 0.09 \\
\hline
\end{tabular}

For Table III, it is illustrated that the alpha is higher in "5-star" index, and lower in each step. The "1-star" index has the lowest value.

In addition, this paper examines to find the Fama-French momentum alpha for 5 years by using Fama-French 4-factor model [27], started from 2003 to 2007 as shown in Table IV. The purpose for this examine is to see the momentum change of Fama-French alpha for 5 years after funds receive the Morningstar rating, as shown in Table IV.

According to the result in Table IV, it is shown that the alpha is high as the rating of "star". The 5-Morningstar funds have the high value of alpha, and separate to each rating.

\section{Fund's Rating and Fama-French Momentum Alpha}

According to paper's question, if funds change rating, Fama-French alpha changes in the same trend or not? To answer this question, the paper evaluates, and monitors the trend for both of funds' performance and funds' Fama-French momentum alpha as shown in Table V.

From Table V, it is shown that the trend for both of funds' performance and funds' alpha goes to the same way, which is the same result as previous study as [8] even they examines in the big market as in Europe. When the rating changes, the alpha changes in the same way. For example, the rating reduces, the alpha reduces. As a result, there is a relation between performance and funds' alpha

\section{Fama-French Momentum and Fund Size}

According to the result of the testing, there are positive correlation between funds' rating and funds' alpha, and negative relation between fund size and funds' rating.

According to the previous study as [8], he found that 5-star rating dropped their performance after receive the rating in 5 years due to the bigger fund size. When fund had the bigger fund size, manager cannot manage the fund as well as he can in the past. Thus, it is one of the factors of funds' performance dropped.

In this study, it shows the same result as [8]. The average fund size of 5-star is much smaller than 1-star. Thus, after 5 -star funds receive the star, the funds should be bigger, and it impacts to drop their performance. 
TABLE IV: FAMA-FrENCH MOMENTUM ALPHA DURING Five YEARS, STARTED FROM 2003 To 2007

\begin{tabular}{|c|c|c|c|c|c|c|}
\hline \multirow[b]{2}{*}{ Code } & \multirow[b]{2}{*}{ Name } & \multicolumn{5}{|c|}{ Fama-French Alpha } \\
\hline & & 2003 & 2004 & 2005 & 2006 & 2007 \\
\hline ABSM & Aberdeen Small Cap Fund & 0.9166 & 0.8859 & 0.8466 & 0.8049 & 0.7728 \\
\hline LHEQO-R & LHEQUITY DIVIDEND FUND-Return Automatically & 0.9283 & 0.8716 & 0.8343 & 0.8250 & 0.8122 \\
\hline LHEQO-A & LHEQUITY DIVIDEND FUND-Accomurate & 0.9554 & 0.9458 & 0.8682 & 0.7954 & 0.7706 \\
\hline LHEQO-D & LHEQUITY DIVIDEND FUND-Dividend & 0.9366 & 0.8326 & 0.8056 & 0.7765 & 0.7188 \\
\hline KFSDIV & Krungsri Dividend Stock Fund & 0.7320 & 0.8112 & 0.8618 & 0.8787 & 0.8826 \\
\hline KFLTFDIV & Krungsri Dividend Stock LTF & 0.7956 & 0.7586 & 0.7696 & 0.7820 & 0.7009 \\
\hline KFVALUE & Krungsri Value Stock Fund & 0.8027 & 0.7732 & 0.7826 & 0.8414 & 0.7905 \\
\hline ABSC-RMF & Aberdeen Smarty Capital Retirement Mutual Fund & 0.8012 & 0.6825 & 0.6389 & 0.6673 & 0.6238 \\
\hline VFOCUS-D & ING Thai Value Focus Equity-Dividend Fund & 0.8122 & 0.8673 & 0.8723 & 0.8821 & 0.9153 \\
\hline KTSE-RMF & Krung Thai Selective Equity RMF & 0.8027 & 0.8012 & 0.6666 & 0.5659 & 0.5544 \\
\hline KTEF & Krung Thai Smart Equity Fund & 0.8132 & 0.8369 & 0.8821 & 0.8825 & 0.9015 \\
\hline KFDIVRMF & Krungsri Dividend Stock RMF & 0.8150 & 0.8121 & 0.8459 & 0.8225 & 0.8271 \\
\hline ABLTF & Aberdeen Long Term Equity Fund & 0.6963 & 0.6902 & 0.6185 & 0.5889 & 0.6015 \\
\hline ABG & Aberdeen Growth Fund & 0.6654 & 0.6754 & 0.5832 & 0.6021 & 0.6015 \\
\hline ABSL & Aberdeen Siam Leaders Fund & 0.6634 & 0.6760 & 0.5813 & 0.5795 & 0.5594 \\
\hline SCBDV & SCB Dividend Stock Open End Fund & 0.6678 & 0.6782 & 0.6593 & 0.6450 & 0.6197 \\
\hline MF-LTF & MFC Islamic Long Term Equity Fund & 0.6812 & 0.6628 & 0.4915 & 0.4459 & 0.4089 \\
\hline CIMB-PRINCIPAL IDIV-D & CIMB-Principal Dividend Income Fund-Dividend & 0.6527 & 0.6283 & 0.5564 & 0.4655 & 0.3697 \\
\hline CIMB-PRINCIPAL IDIV-R & CIMB-Principal Dividend Income Fund-Return Automatically & 0.6167 & 0.5450 & 0.4937 & 0.4142 & 0.3999 \\
\hline CIMB-PRINCIPAL IDIV-A & CIMB-Principal Dividend Income Fund-Accumorate & 0.6970 & 0.6839 & 0.6219 & 0.6170 & 0.6627 \\
\hline T-LOWBETA & Thanachart Low Beta Fund & 0.6450 & 0.6860 & 0.6871 & 0.6630 & 0.5195 \\
\hline BSIRICG & Bualuan Siriphol Corporate Governance & 0.6620 & 0.6754 & 0.6785 & 0.6850 & 0.6896 \\
\hline FAM SET100RMF & Finansa SET100 Retirement Mutual Fund & 0.6340 & 0.7890 & 0.8640 & 0.8820 & 0.9873 \\
\hline HI-DIV & MFC Hi-Dividend Fund & 0.6120 & 0.6340 & 0.6086 & 0.6786 & 0.6384 \\
\hline KFLTFD70 & Krungsri Dividend Stock LTF 70/30 & 0.4820 & 0.5160 & 0.6550 & 0.6903 & 0.6777 \\
\hline ABTED & Aberdeen Thai Equity Dividend Fund & 0.4027 & 0.4447 & 0.4243 & 0.3371 & 0.3733 \\
\hline K-VALUE & K Valued Stock Fund & 0.3070 & 0.3110 & 0.3470 & 0.3330 & 0.2920 \\
\hline SCBSET & SCB SET Index Fund & 0.3420 & 0.3405 & 0.3113 & 0.3239 & 0.3069 \\
\hline KFL 20 PLUS & Krungsri Life Stage 20 Plus Fund & 0.3246 & 0.3076 & 0.3777 & 0.3677 & 0.3718 \\
\hline KK DIVIDEND & KK Dividend Equity Fund & 0.3034 & 0.3267 & 0.4785 & 0.4573 & 0.4292 \\
\hline KK ACT EQ & KK Active Equity Fund & 0.3190 & 0.3142 & 0.3254 & 0.3142 & 0.4832 \\
\hline IN-RMF & Bualuang Infrastructure RMF & 0.3111 & 0.3060 & 0.4901 & 0.4878 & 0.4893 \\
\hline SCBPMO & SCB Permpol Munkhong Open End Fund & 0.2455 & 0.1953 & 0.1565 & 0.1211 & 0.1111 \\
\hline MG-LTF & MFC Global Long Term Equity Fund & 0.1502 & 0.1190 & 0.1243 & 0.1267 & 0.0978 \\
\hline TISCOHD & TISCO High Dividend Equity Fund & 0.1892 & 0.1189 & 0.1359 & 0.0923 & 0.0879 \\
\hline UOBSDF & UOB Smart Dividend-Focused Equity Fund & 0.0987 & 0.0896 & 0.0767 & 0.0687 & 0.0679 \\
\hline
\end{tabular}

This table examines funds' alpha during 5 years, started 2003 to 2007 . The 5-Moringstar funds have the high value of alpha and decrease respectively. The alpha value is the same trend of funds' rating.

TABLE V: FUNDS’ RATING AND FAMA-FRENCH MOMENTUM ALPHA

\begin{tabular}{|c|c|c|c|c|c|c|c|c|c|c|c|}
\hline \multirow[b]{2}{*}{ Code } & \multirow[b]{2}{*}{ Name } & \multicolumn{5}{|c|}{ Morningstar Index } & \multicolumn{5}{|c|}{ Fama-French Alpha } \\
\hline & & 2003 & 2004 & 2005 & 2006 & 2007 & 2003 & 2004 & 2005 & 2006 & 2007 \\
\hline ABSM & Aberdeen Small Cap Fund & 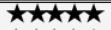 & 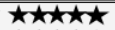 & 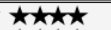 & 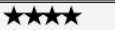 & 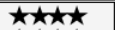 & 0.9166 & 0.8859 & 0.8466 & 0.8049 & 0.7728 \\
\hline LHEQO-R & LHEQUITY DIVIDEND FUND-Return Automatically & 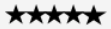 & 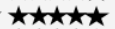 & 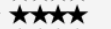 & 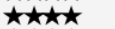 & 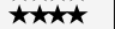 & 0.9283 & 0.8716 & 0.8343 & 0.8250 & 0.8122 \\
\hline LHEQO-A & LHEQUITY DIVIDEND FUND-Accomurate & 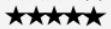 & 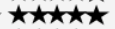 & $\star \star \star \star \star ~$ & 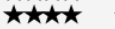 & 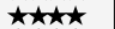 & 0.9554 & 0.9458 & 0.8682 & 0.7954 & 0.7706 \\
\hline LHEQO-D & LHEQUITY DIVIDEND FUND-Dividend & 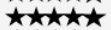 & 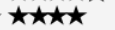 & $\star \star \star \star \star$ & 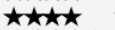 & 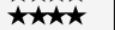 & 0.9366 & 0.8326 & 0.8056 & 0.7765 & 0.7188 \\
\hline KFSDIV & Krungsri Dividend Stock Fund & 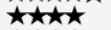 & $\star \star \star \star \star$ & 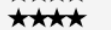 & 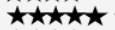 & 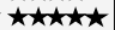 & 0.7320 & 0.8112 & 0.8618 & 0.8787 & 0.8826 \\
\hline KFLTFDIV & Krungsri Dividend Stock LTF & 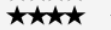 & 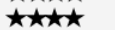 & $\hat{\star \star \star \star \star ⿱ 亠 幺}$ & $\star \star \star \star \star$ & 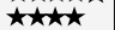 & 0.7956 & 0.7586 & 0.7696 & 0.7820 & 0.7009 \\
\hline KFVALUE & Krungsri Value Stock Fund & 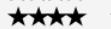 & $\hbar \hbar \star \hbar$ & $\hat{\star} \hat{\star \star \hbar \hbar}$ & 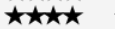 & 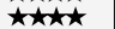 & 0.8027 & 0.7732 & 0.7826 & 0.8414 & 0.7905 \\
\hline ABSC-RMF & Aberdeen Smarty Capital Retirement Mutual Fund & $\star \star \star \star \star ~$ & $\star \star \star \star$ & $\star \star \star \star$ & 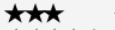 & $\star \star \star$ & 0.8012 & 0.6825 & 0.6389 & 0.6673 & 0.6238 \\
\hline VFOCUS-D & ING Thai Value Focus Equity-Dividend Fund & $\hbar \hbar \star \hat{\star}$ & 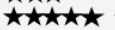 & 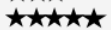 & 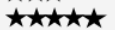 & $\hat{\star \star \star \star \star \star \star \star ~}$ & 0.8122 & 0.8673 & 0.8723 & 0.8821 & 0.9153 \\
\hline KTSE-RMF & Krung Thai Selective Equity RMF & $\star \star \star \star$ & $\star \star \star \star \star ~$ & $\star \star \star \star$ & $\star \star \star$ & $\star \star \star$ & 0.8027 & 0.8012 & 0.6666 & 0.5659 & 0.5544 \\
\hline KTEF & Krung Thai Smart Equity Fund & $\hat{\star \star \star \star \star \star ~}$ & $\hat{\star} \hbar \star \hat{\star}$ & $\hat{\star \star \star \star \star \star \star \star ~}$ & $\hat{\star \star \star \star \star \star \star ~}$ & 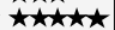 & 0.8132 & 0.8369 & 0.8821 & 0.8825 & 0.9015 \\
\hline KFDIVRMF & Krungsri Dividend Stock RMF & $\star \star \star \star \star$ & 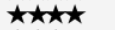 & $\star \star \star \star \star$ & $\star \star \star \star \star$ & $\star \star \star \star \star$ & 0.8150 & 0.8121 & 0.8459 & 0.8225 & 0.8271 \\
\hline ABLTF & Aberdeen Long Term Equity Fund & $\star \star \star$ & $\star \star \star$ & $\star \star \star \star$ & $\star \star \star$ & $\star \star \star$ & 0.6963 & 0.6902 & 0.6185 & 0.5889 & 0.6015 \\
\hline ABG & Aberdeen Growth Fund & $\star \star \star$ & $\star \star \star$ & $\star \star \star \star$ & $\star \star \star \star$ & $\star \star \star$ & 0.6654 & 0.6754 & 0.5832 & 0.6021 & 0.6015 \\
\hline ABSL & Aberdeen Siam Leaders Fund & $\star \star \star$ & $\star \star \star$ & $\star \star \star \star$ & $\star \star \star x$ & & 0.6634 & 0.6760 & 0.5813 & 0.5795 & 0.5594 \\
\hline SCBDV & SCB Dividend Stock Open End Fund & $\star \star \star$ & 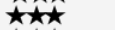 & 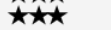 & $\hbar \star \star \star$ & $\hat{\star} \star \hat{\star}$ & 0.6678 & 0.6782 & 0.6593 & 0.6450 & 0.6197 \\
\hline MF-LTF & MFC Islamic Long Term Equity Fund & & $\star \star \star \star$ & $\star \star$ & $\star \star$ & $\star \star$ & 0.6812 & 0.6628 & 0.4915 & 0.4459 & 0.4089 \\
\hline CIMB-PRINCIPAL IDIV-D & CIMB-Principal Dividend Income Fund-Dividend & $\star \star \star$ & $\star \star \star \star$ & $\star \star \star$ & 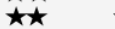 & 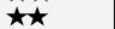 & 0.6527 & 0.6283 & 0.5564 & 0.4655 & 0.3697 \\
\hline CIMB-PRINCIPAL IDIV-R & CIMB-Principal Dividend Income Fund-Return Automatically & $\star \star \star$ & $\star \star$ & $\star \star$ & $\star \star$ & $\star \star \star$ & 0.6167 & 0.5450 & 0.4937 & 0.4142 & 0.3999 \\
\hline CIMB-PRINCIPAL DIV-A & CIMB-Principal Dividend Income Fund-Accumorate & $\star \star \star$ & $\star \star \star$ & $\star \star \star \star$ & 0 & $\star \star \star$ & 0.6970 & 0.6839 & 0.6219 & 0.6170 & 0.6627 \\
\hline T-LOWBETA & Thanachart Low Beta Fund & 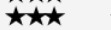 & 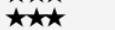 & 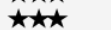 & 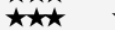 & $\star \star \star$ & 0.6450 & 0.6860 & 0.6871 & 0.6630 & 0.5195 \\
\hline BSIRICG & Bualuan Siriphol Corporate Governance & $\star \star \star$ & $\star \star \star x$ & $\star \star \star$ & $\star \star \star$ & $\star \star \star$ & 0.6620 & 0.6754 & 0.6785 & 0.6850 & 0.6896 \\
\hline FAM SET100RMF & Finansa SET100 Retirement Mutual Fund & $\star \star \star$ & $\star \star \star \star \star$ & 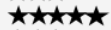 & 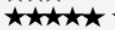 & 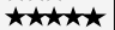 & 0.6340 & 0.7890 & 0.8640 & 0.8820 & 0.9873 \\
\hline HI-DIV & MFC Hi-Dividend Fund & $\star \star \star$ & $\star \star \star \star$ & $\star \star \star$ & $\star \star \star$ & $\star \star \star$ & 0.6120 & 0.6340 & 0.6086 & 0.6786 & 0.6384 \\
\hline KFLTFD70 & Krungsri Dividend Stock LTF 70/30 & $\star \star$ & $\hat{\star \star \star \star \star ~}$ & $\hat{\star \star \star \star \star \star ~}$ & $\hat{\star} \hat{\star \star \star \star \star ~}$ & $\hat{\star \star \star \star \star \star ~}$ & 0.4820 & 0.5160 & 0.6550 & 0.6903 & 0.6777 \\
\hline ABTED & Aberdeen Thai Equity Dividend Fund & $\star \star$ & $\star \star$ & $\star \star$ & $\star \star$ & $\star \star$ & 0.4027 & 0.4447 & 0.4243 & 0.3371 & 0.3733 \\
\hline K-VALUE & K Valued Stock Fund & $\star \star$ & $\hbar \star$ & $\hat{\star} \hat{\star}$ & $\hat{\star \star}$ & $\hat{\star} \hat{\star}$ & 0.3070 & 0.3110 & 0.3470 & 0.3330 & 0.2920 \\
\hline SCBSET & SCB SET Index Fund & $\star \star$ & $\hat{\star} \hat{\star}$ & $\tilde{\star}$ & $\hat{\star} \hat{\star}$ & 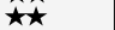 & 0.3420 & 0.3405 & 0.3113 & 0.3239 & 0.3069 \\
\hline KFL 20 PLUS & Krungsri Life Stage 20 Plus Fund & $\star \star$ & $\hbar \star \star$ & $\star \star$ & 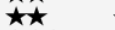 & $\star \star$ & 0.3246 & 0.3076 & 0.3777 & 0.3677 & 0.3718 \\
\hline KK DIVIDEND & KK Dividend Equity Fund & $\hbar \star \star$ & $\hbar \star \star$ & $\star \star \star$ & $\star \star \star$ & $\hbar \star \star \star$ & 0.3034 & 0.3267 & 0.4785 & 0.4573 & 0.4292 \\
\hline KK ACT EQ & KK Active Equity Fund & $\star \star$ & $\star \star$ & $\star \star$ & $\star \star$ & $\star \star \star \star$ & 0.3190 & 0.3142 & 0.3254 & 0.3142 & 0.4832 \\
\hline IN-RMF & Bualuang Infrastructure RMF & $\hat{\star \star}$ & $\hbar \star$ & 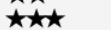 & $\star \star \star \star$ & $\star \star \star \star ~$ & 0.3111 & 0.3060 & 0.4901 & 0.4878 & 0.4893 \\
\hline SCBPMO & SCB Permpol Munkhong Open End Fund & $\star$ & $\star$ & $\star$ & $\star$ & $\star$ & 0.2455 & 0.1953 & 0.1565 & 0.1211 & 0.1111 \\
\hline MG-LTF & MFC Global Long Term Equity Fund & $\star$ & $\star$ & $\star$ & $\star$ & $\star$ & 0.1502 & 0.1190 & 0.1243 & 0.1267 & 0.0978 \\
\hline TISCOHD & TISCO High Dividend Equity Fund & $\star$ & $\star$ & $\star$ & $\star$ & $\star$ & 0.1892 & 0.1189 & 0.1359 & 0.0923 & 0.0879 \\
\hline UOBSDF & UOB Smart Dividend-Focused Equity Fund & $\star$ & $\star$ & $\star$ & $\star$ & $\star$ & 0.0987 & 0.0896 & 0.0767 & 0.0687 & 0.0679 \\
\hline
\end{tabular}

This table compares the trend of both of funds' performance and funds' alpha, which is shown that it goes into the same way for both of them. When the rating changes, the alpha changes accordingly.

\section{CONCLUSION}

This paper has examined the correlation between funds' returns, and funds' performance, for 36 Thai "star" mutual funds during five years, started from 2003 to 2007.

For the first part of the examination in the funds' return and funds' performance relationship, the paper uses Fama-French four-factor model for analysis. This model is applied by adding liquidity to Fama-French three-factor model. To explain some factors in Thai funds, this model included market return, firm size, book-to market ration, and liquidity ratio. 
Moreover, this paper splits "star" funds into 3 main groups that are above-average funds (5-Morningstar funds, and 4-Morningstar funds), average funds (3-Morningstar funds), and below-average funds (2-Morningstar funds, and 1-Morningstar funds). Most of above-average and average funds dropped their performance. The below average ones increased or stayed stable their performance.

This paper has analyzed these 36 "star" funds by Fama-French momentum alpha, and compared alpha with funds' rating to find the relationship between those two analysis. The paper's result suggests that there is a positive relationship between performance and Morningstar rating, which is the same result as previous studies even in different market.

In addition, this paper has found the reason in part of performance trend change. It shows the negative relation between funds' scale, and funds' performance, which is agree with the previous studies that most of smallest funds can easily manage. Thus, the manager can put all money into the optimal investment, and get the higher return.

However, there are a number of methods to analyze the funds' performance (e.g., Jensen's alpha or Shape ratio). This paper should extent to compare the result from those methods, and find the most suitable methods for Thai stock market.

\section{ACKNOWLEDGMENT}

I am deeply thank you to Associate Professor Ph.D. AekkachaiNittaagasetwat for his valuable advice, which helps to complete this empirical study.

I would like to give a special thank you to my family for their patient, and support me toward the complement of this study.

Additionally, I would like to thanks those whose names are not mentioned here but have greatly inspired and encouraged me until this study becomes complete.

\section{REFERENCES}

[1] R. F. Whitelaw, "Time variations and covariations in the expectation and volatility of stock market returns," Journal of Finance, 1997, Vol. 49, PP. 515-541

[2] J. Huang, D. K. Wei, and H. Yan, Investor Learning and Mutual Fund Flows, Working Paper, Chicago Meeting, 2012

[3] Morningstar. (2013). Morningstar Ratings (Star Ratings) and Their Limitations. [Online] Available: http://www.morningstar.com.au/Funds/MorningstarRatings

[4] G. D. Del and A. T. Paula, "The effect of morningstar ratings on mutual fund flows," Working Paper, University of Oregon Department of Finance, 2002

[5] C. Blake and M. Matthew, "Morningstar rating and mutual fund performance," Journal of Financial and Quantitative Analysis, 2000, vol. 35, PP. 451-483

[6] Grinblatt and Titman, "The persistence of mutual fund performance," Journal of Finance, 1992, vol. 47, PP. 1977-1984

[7] E. J. Elton, G. J. Martin, and B. R. Christopher, "The persistence of risk-adjusted mutual fund performance," Journal of Business, 1996, vol. 69, PP. 133-157

[8] M. R. Morey, "Kiss of death: A 5-star morningstar mutual fund rating?" Paper of Pace University (Department of Finance), One Pace Plaze, September 2003, pp. 1-17

[9] J. Y. Champbell, "Stock returns and the term structure," Journal of Financial Economics, 1987, vol. 18, PP. 373-399
[10] R. K. French, G. W. Schewert, and R. F. Stambaugh, "Expected stock returns and volatility," Journal of Financial Economics, 1987, vol. 19, PP. 3-30

[11] R. L. Glosten, R. Jagannathan, and D. E.Runkle, "On the relation between the expected value and the volatility of the nominal excess return on stocks," Journal of Finance, 1993, vol. 48, pp. 1779-1801

[12] O. Roger and B. Dennis, "European mutual fund performance," European Financial Management, 2002, vol. 8, no. 1, pp. 75-101

[13] T. R. Billie and P. R. DeGennaro, "Stock returns and volatility," Journal of Financial and Quantitative Analysis, 1990, vol. 25, no. 2, June 1990, pp. 203-214

[14] J. A. Busse, "Volatility timing in mutual funds: Evidence from daily returns," The Review of Financial Studies, Winter 1999, vol. 12, no. 5 , pp. 1009-1041

[15] J. L. Devore, "Probability and statistics: For engineering and sciences," Duxbury Thomson Learning, 2000

[16] A. Perold and R. S. Salomon, "The right amount of assets under management," Financial Analysts Journal, 1991, vol. 47, no. 3, pp. 31-39

[17] R. Lowenstein, "Frightened funds: Is there a master in the house?" Wall Street Journal, 1997, November 20, pp. C1

[18] S. Brown and G. William, "Performance persistence," Journal of Finance, 1995, vol. 50, pp. 679-698

[19] M. M. Carhart, "On persistence in mutual fund performance," Journal of Finance, 1997, vol. 52, pp. 57-827

[20] E. J. Elton, G. J. Martin, and B. R. Christopher, "The persistence of risk-adjusted mutual fund performance," Journal of Business, 1996, vol. 69 , pp. 133-157

[21] R. F. Whitelaw, "Time variations and covariations in the expectation and volatility of stock market returns," Journal of Finance, 1997, vol. 49, pp. 515-541

[22] H. Darry, J. Patel, and R. Zeckhauser, "Hot hands in mutual funds: Short-run persistence of relative performance, Journal of Finance, 1993, vol. 48, pp. 93-130, 1974-1988,

[23] K. Ajay, "Performance changes following top management turnover: Evidence from open-end mutual funds," Journal of Financial and Quantitative Analysis, 2001, vol. 36, pp. 371-393

[24] Morningstar, co. (2013). Construction Rules for Morningstar Commudity Indexes. Moringstar Methodology paper. [Online] Version $3.3 . \quad$ Available: http://corporate.morningstar.com/US/documents/Indexes/Constructio nRulesCommodityIndex.pdf

[25] Morningstar, co. (2013). Morningstar fund. The list of Monringstar funds. [Online] Available: http://tools.morningstarthailand.com/th/fundscreener/results.aspx?Site $=$ th $\&$ Universe $=$ FONLD $\% 24 \% 24$ ALL $\&$ Rating $=0 \% 7 \mathrm{c} 0 \% 7 \mathrm{c} 0 \% 7 \mathrm{c} 0 \% 7$ c1\&LanguageId=th-TH

[26] E. F. Fama and R. K. French, "Common risk factors in the returns on stocks and bonds," Journal of Financial Economics, 1993, vol. 33, no. 1, pp. 3-56

[27] J. Puksamatanan, "The liquidity and stock returns: Empirical evidence in Thailand," Working paper, National Institute of Development Administration (NIDA)-Business, 2011.

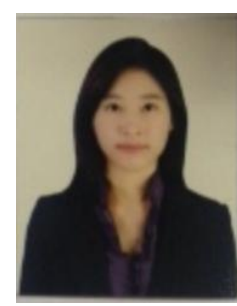

Chollaya Chotivetthamrong was born in Bangkok, Thailand in 1984. She is studying in doctoral degree in Finance in National Institute of Development Administration, Bangkok. She educated a master degree in Engineering Business Management, University of Warwick, UK and in Engineering Managerment, Chulalongkorn University, Bangkok. Her bachelor degree was in Industrial engineering (with honor), Kasetsart University, Bangkok. She is working at Exxonmobil, Ltd. as Global Operations Support analyst, based in Bangkok. Her current position is to stewardship overall company's performance, and report itto the head office in Fairfax. Before working in this position. She used to work as Asia Pacific Operations Support Supervisor, Malaysia Delivery Supervisor, Singapore and Hong Kong Delivery Supervisor, Asia Pacific Delivery System Expert User, and Thailand Delivery Analyst. Based on her experience, and education background, her research interestsare inmutual fund performance, fund flow or sensitivity, financial, operations research, and logistics topics. 